\title{
ALTERATIONS OF THE MYENTERIC PLEXUS OF THE ILEUM AND THE DESCENDING COLON CAUSED BY Toxoplasma gondii (GENOTYPE III)
}

\author{
Elaine Yae Yamashita Sugauara', Débora de Mello Gonçales Sant'Ana', Elton Carlos de Almeida', \\ Anderson Brunetti Reis', Aristeu Vieira da Silva², Eduardo José de Almeida Araújo'
}

\begin{abstract}
Alterations caused by a genotype III strain of Toxoplasma gondii were assessed with respect to the number and the morphometry of the myenteric neurons in the terminal ileum and the descending colon. Eighteen rats were divided into four groups: Acute Control Group (ACG, $n=4$ ); Acute Experimental Group (AEG, n=4); Chronic Control Group (CCG, n=5) and Chronic Experimental Group (CEG, n=5). NaCl solution was administered through gavage to the animals in the ACG and CCG. Toxoplasma gondii tachyzoites $\left(10^{4}\right)$ from a genotype III strain were orally administered to the AEG and CEG. Acute Groups were died after 24 hours, and the Chronic Groups after 30 days. Neuronal loss was not observed in both organs. The neurons atrophied in the terminal ileum as the opposite occurred with the neurons at the descending colon during the chronic phase of infection. In the terminal ileum, the neurons atrophied during the chronic phase of the infection as no alteration was found during the acute phase. For the descending colon, the neurons became hypertrophic during the chronic infection in opposition to the atrophy found during the acute phase.
\end{abstract}

KEY WORDS: enteric nervous system, toxoplasmosis, morphology.

\begin{abstract}
Alterações do plexo mientérico do íleo e cólon descendente causadas por Toxoplasma gondii (genótipo III)
Resumo - Objetivou-se avaliar as alterações causadas por uma cepa genótipo III de Toxoplasma gondii, sobre o número e a morfometria de neurônios mientéricos, do íleo terminal e do cólon descendente. Dividiuse dezoitos ratos em quatro grupos: controle agudo (GCA, $n=4$ ), experimental agudo (GEA, $n=4$ ), controle crônico ( $G C C, n=5$ ) e experimental crônico ( $G E C, n=5$ ). Os animais do $G C A$ e $G C C$ receberam solução de $\mathrm{NaCl}$ por gavagem, e os animais do GEA e GEC $10^{4}$ taquizoítos de uma cepa genótipo III de T. gondii por via oral. Os grupos agudos após 24 horas foram mortos e os crônicos após 30 dias. Observou-se que não houve perda neuronal em ambos os órgãos. No íleo terminal, os neurônios atrofiaram-se na fase crônica da infecção, enquanto nenhuma alteração ocorreu na fase aguda. Já no cólon descendente, os neurônios tornaram-se hipertróficos na fase crônica da infecção, em oposição à atrofia observada na fase aguda.
\end{abstract}

PALAVRAS-CHAVE: sistema nervoso entérico, toxoplasmose, morfologia.

The enteric nervous system (ENS) is a complex net of intramural innervation of the digestive tube capable of regulating the motility reflexes and coordinating the processes including secretion and absorption, controlling the blood flow and modulating the immune and endocrine functions. Besides, it presents a number of plexus, two ganglionic: myenteric and submucosal. The ENS distinguishes itself from the rest of the peripheral nervous system as it presents a great deal of neurons (similar to those found at the spinal cord) which form circuits capable of interacting with the internal environment of the digestive tube independently of the central nervous system (CNS). This is due to its having sensitive neurons, intrinsic primary afferent neurons, interneurons, and excitatory and inhibitory motor neurons, structurally interconnected even more complexly by considering the animals' evolutionary scale'. Neurons are cells which may have their functioning altered by elements of the diet and by inflammatory processes which may develop focalized necrosis ${ }^{2}$ and/or alter its metabolism ${ }^{3}$. There are reports of some parasites

\footnotetext{
'Experimental Neurogastroenterology Laboratory, UNIPAR, Umuarama PR, Brazil; ${ }^{2}$ Preventive Veterinary Laboratory, UNIPAR, Umuarama PR, Brazil. Financial Suport: UNIPAR.

Received 12 February 2008, received in final form 5 May 2008. Accepted 5 June 2008.

Dr. Eduardo José de Almeida Araújo - Experimental Neurogastroenterology Laboratory / Universidade Paranaense (UNIPAR) - Praça Mascarenhas de Moraes 4282 - 87502-210 Umuarama PR - Brasil. E-mail: eduardoaraujo@unipar.com.br
} 
which can break out some of these problems within the ENS such as Trypanosoma $\mathrm{cruzi}^{4}$, Schistosoma mansoni ${ }^{5}$ $\mathrm{e}$, and Schitosoma japonicum ${ }^{6}$. On the other hand, there are no descriptions of studies assessing the consequences of infections by Toxoplasma gondii (T. gondii) for enteric neurons even though there a number of researches and clinical reports indicating the pathogenicity of this parasite for the CNS neurons ${ }^{2}$.

T. gondii is a protozoan phylum apicomplexa which may be located at the intestinal epithelium of felidae (definite hosts) and in different tissue of homeothermic animals, including men. The felidae are the only definite hosts as they are the only animals presenting an enteroepithelial cycle with sexual reproduction of the parasite, with the formation of oocytes which are eliminated through the feces. Millions of oocytes may be eliminated at a single evacuation, remaining viable at the environment for a long period depending on the environmental conditions and humidity. Another cycle of the development of the parasite is the extraintestinal manifestation - either for the definite host or the intermediary - here there is asexual development of the parasite with the formation of tachyzoites and bradyzoites. The intermediary host is infected by ingesting raw or undercooked meat containing tissue cysts as well as by ingesting water or food contaminated with oocytes. After ingestion, the walls of the cysts or oocytes are ruptured by the enzymatic degradation and the infectious form of the parasite is released within the intestinal lumen, which quickly invades and multiplies inside the host cells, where they differ into tachyzoites ${ }^{7}$. The $T$. gondii holds a population structure highly clonal ${ }^{8}$ based on the three lines I, II, and III. Strains isolated in Brazil have demonstrated that Genotypes I and III are highly virulent ${ }^{9}$. The initial symptoms of toxoplasmosis may include skin irritation, fever, increase of lymph node, and visual perturbation, such as chorioretinitis and uveitis ${ }^{10}$. With respect to the congenital infection, it usually occurs when the woman is exposed to the infection during pregnancy as the parasites easily cross the placenta. As most of these infections are asymptomatic, a few of the cases may result in abortion, stillbirths, or lesions of the fetal nervous system. Children severely taken ill present chorioretinitis and brain necrosis and there may be hepatosplenomegaly, hepatic insufficiency, convulsions, and hydrocephalus ${ }^{1}$. It is an opportunistic infection which strikes immunocompromised individuals such as those infected with the HIV?. In animals - such as cats and dogs, toxoplasmosis primarily affects the nervous system, the gastrointestinal tube, the ocular region, and the respiratory system; besides other clinical manifestations including fever, depression, diarrhea, respiratory difficulty, convulsion, hyperexcitability, tremor, psychological weakness, vomiting, and oral ulceration ${ }^{12}$. Myocardi- tis, lymphonopathy, chorioretinitis, pancreatitis, anemia, intestinal granuloma were associated with toxoplasmo$\mathrm{sis}^{12}$. It may also cause abortion in sheep, pigs, and rabbits infected during pregnancy ${ }^{7}$. Rats infected with T. gonddi develop good humoral and cell immune response within a short length of time ${ }^{13}$. In relation to the clinical evolution and the placental transmission, toxoplasmosis in rats and humans is alike; therefore, infection in rats may be used as a model for human toxoplasmosis ${ }^{14}$.

As a result of such neurological and gastrointestinal alterations caused by $T$. gondii, this study assesses the possible alterations caused by the Genotype III strain of this parasite in the number and morphometry of the myenteric neurons of the terminal ileum and the descending colon of rats.

\section{METHOD}

\section{Experimental groups}

The experimental protocol was previously approved by the UNIPAR Ethics Committee in Researches Involving Animal Experimentation.

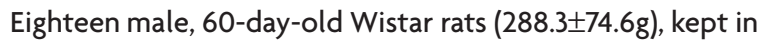
boxes with individual grids, in a bioterium constantly at $25{ }^{\circ} \mathrm{C}$ with 12-hr light/12-hr dark alternate cycles, were used. All the animals received rat chow (NUVITAL ${ }^{\circledast}$ ) and water ad libitum.

The animals were divided into 4 groups: Acute Control Group (ACG, $n=4$ ); Acute Experimental Group (AEG, $n=4$ ); Chronic Control Group (CCG, n=5) and Chronic Experimental Group (CEG, $n=5$ ). $\mathrm{NaCl}$ solution was administered through gavage to the animals in the ACG and CCG. T. gondii tachyzoites $\left(10^{4}\right)$ from a Genotype III strain isolated from dog brains with neurological symptomatology ${ }^{9}$ were orally administered to the AEG and CEG. Acute Groups were died after 24 hours, and the Chronic Groups after 30 days.

The animals were intramuscularly anesthetized using the following protocol: Acepram ${ }^{\oplus} 1.26 \mathrm{~mL} / \mathrm{kg}+\operatorname{Ketalar}^{\oplus}(10 \mathrm{~mL}) 1.26$ $\mathrm{mL} / \mathrm{kg}+$ Rompum $^{\oplus}(2 \%) 0.42 \mathrm{~mL} / \mathrm{kg}+$ Atropina $^{\circledast}(1 \%) 0.22 \mathrm{~mL} /$ $\mathrm{kg}^{15}$ in order to collect blood by puncturing the retro-orbital plexus (only from CCG and CEG groups), and laparotomy for the removal of the terminal ileum and the descending colon. The terminal ileum was considered as the distal portion to the initial ileocecal fold. Then, the animals were died by anesthetic deepening.

The blood collected was centrifuged and the serum was used to detect the presence of antibodies against $T$. gondii by the direct agglutination method ${ }^{16}$.

\section{Obtaining the whole-mount preparations}

The terminal ileum and the descending colon from each animal were measured with respect to length and width by using a tape measure and a millimetric ruler as they were removed. Because of the difficulty on automatically distinguishing the terminal ileum of the jejunum, these measurements were made by 
considering these two organs together. Then, they were washed in a $9 \%-\mathrm{NaCl}$ solution, filled and immersed in a fixation solution containing acetic formol for 48 hours. Next, they were dissected with the aid of a stereomicroscope by removing the mucosa and the submucosal network. Therefore, the whole-mounted used for this study were constituted by the muscularis externa (where the myenteric plexus is located) and the serous membrane, and stained according to the Giemsa technique ${ }^{17}$. The possible presence of chromatolysis as a consequence of the neuronal lesion provoked by the parasite was assessed.

\section{Quantitative analysis}

The total number of myenteric neurons was counted in 120 microscopic fields, uniformly distributed all over the intestinal circumference ${ }^{18}$ of each specimen, totalizing an area of $25.2 \mathrm{~mm}^{2}$ per animal. For that, a Motic BL220A binocular microscope with $40 x$ objective was used. The neurons positioned at the edges of each field were counted in alternated fields.

\section{Morphometric analysis}

The area of the soma, cytoplasm, and the nucleus of 300 neurons of the myenteric plexus of the terminal ileum and the descending colon (uniformly distributed all over the intestinal circumference) of the animals from each group was measured with the software Image Motic Plus, version 2.0. A microscope with a 2.0 Megapixel digital camera (MOTICAM 2000) connected to a computer was used for that. From these values, neurons were divided into classes by considering the soma area $\left(50 \mu \mathrm{m}^{2}\right.$ interval) and the nucleus-soma ratio (0.10 intervals).

\section{Statistic analysis}

All the data were initially submitted to the KolmogorovSmirnov test for the verification of their distribution type. Normal distribution data were expressed as mean \pm standard deviation, and the free distribution ones were expressed as median and percentiles 25 and 75 (P25; P75). The Student's test (normal distribution data) and Mann-Whitney (free distribution data) were used in order to compare Control and Experimental Group, by considering $\mathrm{p}<0.05$ significant values.

\section{RESULTS}

According to the serologic exam, the animals from the CEG group presented positive results with respect to the presence of anti-T. gondii whereas the CCG group presented negative results. Values obtained concerning the dimensions of the collected organs, and the quantitative and morphometric analysis of the myenteric neurons are presented on Tables 1, 2, and 3, respectively; as well as il-

Table 1. Length, width and area of the ileum-jejunum and the total colon from healthy rats (Control Group - CG) and submitted to infection by a Genotype III T. gondii strain (Experimental Group - EG).

\begin{tabular}{llccc}
\hline Organ & Group & Lenght $(\mathrm{cm})$ & Width $(\mathrm{cm})$ & Area $\left(\mathrm{cm}^{2}\right)$ \\
\hline Ileum-jejunum & ACG & $107.25 \pm 2.36$ & $1.40 \pm 0.08$ & $150.10 \pm 8.27$ \\
& AEG & $102.75 \pm 3.77$ & $1.38 \pm 0.15$ & $141.23 \pm 15.77$ \\
& CCG & $109.16 \pm 5.62^{*}$ & $1.68 \pm 0.08^{*}$ & $183.33 \pm 11.92^{*}$ \\
& CEG & $100.94 \pm 3.31^{*}$ & $1.50 \pm 0.12^{*}$ & $151.18 \pm 9.26^{*}$ \\
Total colon & ACG & $15.45 \pm 1.32$ & $2.15 \pm 0.37$ & $33.11 \pm 5.74$ \\
& AEG & $14.88 \pm 2.78$ & $1.73 \pm 0.30$ & $26.15 \pm 9.38$ \\
& CCG & $15.86 \pm 1.18$ & $2.16 \pm 0.29$ & $34.31 \pm 5.84$ \\
& CEG & $16.08 \pm 3.13$ & $2.10 \pm 0.30$ & $33.93 \pm 8.54$ \\
\hline
\end{tabular}

Values presented as mean \pm standard deviation. Values denoted by asterisks on the same column are significantly different $(p<0.05)$.

Table 2. Population density of the neurons in $25.2 \mathrm{~mm}^{2}$ (120 microscopic field) of the terminal ileum and the descending colon of healthy rats (Control Group - CG) and the submitted to the infection by a Genotype III T. gondii strain (Experimental Group - EG).

\begin{tabular}{ccc}
\hline Group & Organ & Number of neurons in $25.2 \mathrm{~mm}^{2}$ \\
\hline ACG & Terminal ileum & $3,912.8 \pm 1,044.7$ \\
AEG & & $4,662.4 \pm 369.6$ \\
CCG & & $3,522.8 \pm 603.6$ \\
CEG & & $4,351.2 \pm 804.9$ \\
ACG & Descending colon & $4,983.8 \pm 181.8$ \\
AEG & & $5,133.0 \pm 458.2$ \\
CCG & $4,163.8 \pm 336.4$ \\
CEG & & $5,035.6 \pm 1,379.7$ \\
\hline
\end{tabular}


Table 3. Soma area, nucleus area, cytoplasm area, and the nucleus-soma area ratio of myenteric neurons of the terminal ileum and descending colon from healthy rats (Control Group - CG) and the submitted to a Genotype III T. gondii strain (Experimental Group - EG).

\begin{tabular}{llcccc}
\hline Organ & Group & $\begin{array}{c}\text { Soma area } \\
\left(\mu \mathrm{m}^{2}\right)\end{array}$ & $\begin{array}{c}\text { Nucleus area } \\
\left(\mu \mathrm{m}^{2}\right)\end{array}$ & $\begin{array}{c}\text { Cytoplasm area } \\
\left(\mu \mathrm{m}^{2}\right)\end{array}$ & $\begin{array}{c}\text { Soma-nucleus } \\
\text { area ratio }\end{array}$ \\
\hline Terminal ileum & ACG & $238.9(134.2 ; 826.5)$ & $95.3(47.8 ; 330.2)$ & $145.3(79.9 ; 466.0)$ & $0.39(0.31 ; 0.49)^{*}$ \\
& AEG & $258.4(134.3 ; 828.2)$ & $99.0(48.6 ; 290.8)$ & $155.2(78.9 ; 496.2)$ & $\begin{array}{c}0.38(0.29 ; 0.48)^{*} \\
\end{array}$ \\
& CCG & $333.2(164.4 ; 845.2)^{*}$ & $123.81(58.4 ; 309.5)^{*}$ & $207.7(100.0 ; 511.8)^{*}$ & $0.37(0.30 ; 0.46)$ \\
& CEG & $161.5(95.7 ; 515.8)^{*}$ & $56.4(33.2 ; 202.5)^{*}$ & $104.2(58.7 ; 289.5)^{*}$ & $0.36(0.29 ; 0.45)$ \\
Descending colon & ACG & $135.0(98.3 ; 185.4)^{*}$ & $69.8(50.7 ; 94.6)^{*}$ & $60.9(42.4 ; 94.2)^{*}$ & $0.52(0.44 ; 0.59)^{*}$ \\
& AEG & $124.4(87.6 ; 170.1)^{*}$ & $62.9(43.8 ; 84.8)^{*}$ & $57.7(39.7 ; 88.7)^{*}$ & $0.50(0.42 ; 0.58)^{*}$ \\
& CCG & $120.2(74.1 ; 182.9)^{*}$ & $60.5(38.0 ; 86.1)^{*}$ & $55.8(34.9 ; 93.9)^{*}$ & $0.49(0.41 ; 0.57)$ \\
& CEG & $157.3(115.8 ; 209.9)^{*}$ & $74.8(55.3 ; 97.8)^{*}$ & $75.4(50.8 ; 114.3)^{*}$ & $0.49(0.40 ; 0.57)$ \\
\hline
\end{tabular}

Values presented as median (P25; P75). Values denoted by asterisks on the same column are significantly different $(\mathrm{p}<0.05)$.

Table 4. Correlation among the soma area, the cytoplasm, and the nucleus of myenteric neurons of the terminal ileum and the descending colon from healthy rats (Control Group - CG) and submitted to infection by a Genotype III T. gondii strain (Experimental Group - EG).

\begin{tabular}{llccc}
\hline Organ & Group & $\begin{array}{c}\text { Soma area X } \\
\text { Nucleus area }\end{array}$ & $\begin{array}{c}\text { Soma area X } \\
\text { Cytoplasm area }\end{array}$ & $\begin{array}{c}\text { Nucleus area X } \\
\text { Cytoplasm area }\end{array}$ \\
\hline Terminal ileum & ACG & 0.91 & 0.96 & 0.77 \\
& AEG & 0.88 & 0.97 & 0.73 \\
& CCG & 0.90 & 0.97 & 0.77 \\
& CEG & 0.91 & 0.98 & 0.81 \\
Descending colon & ACG & 0.89 & 0.93 & 0.67 \\
& AEG & 0.84 & 0.93 & 0.59 \\
& CCG & 0.96 & 0.98 & 0.87 \\
& CEG & 0.82 & 0.96 & 0.62 \\
\hline
\end{tabular}

All the values are significant, considering $5 \%$ the level of significance.
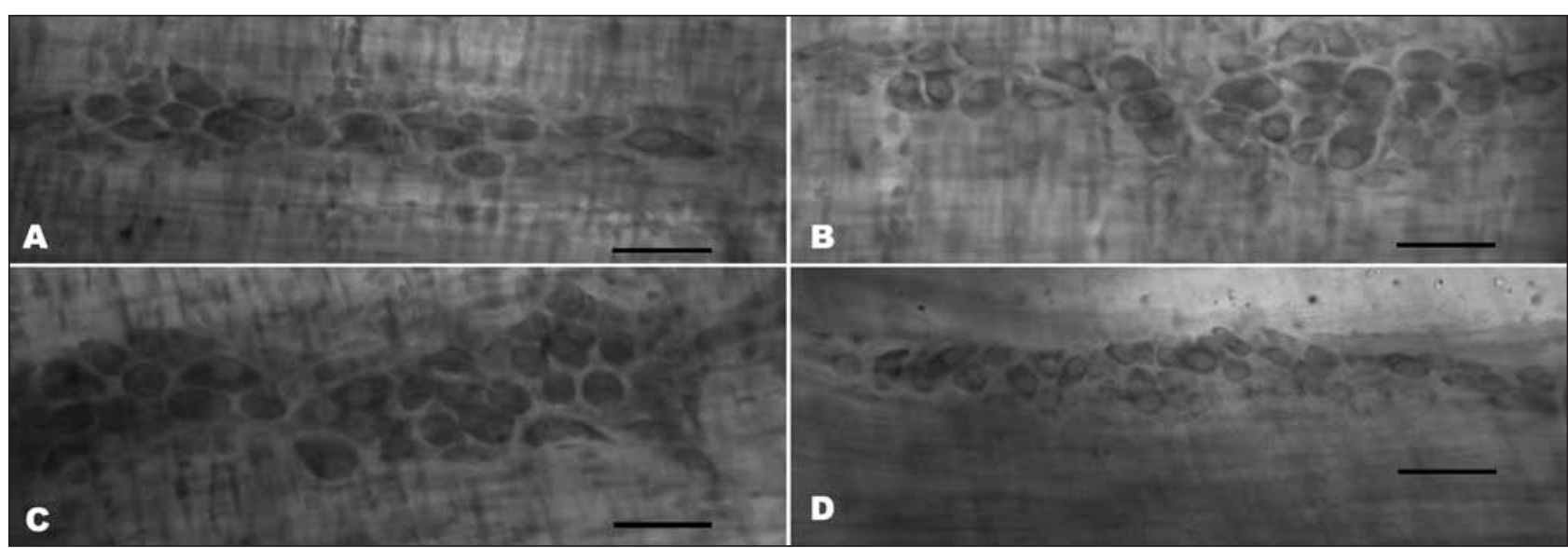

Fig 1. Myenteric ganglions from rat ileum, healthy ( $A$ and $C)$, or infected with a Genotype III Toxoplasma gondii strain (B and D). Note that there were not any alterations of the perikarion area between the control group (A) and the experimental group (B) during the acute phase (24 hr) of the infection, yet atrophy was found for the experimental group (D) in relation to the control group (C) during the chronic phase (30 days). Giemsa, bar: $40 \mu \mathrm{m}$.

lustrated on Figures 1 and 2. Chromatolysis was not found for the neurons in these groups. The degree of correlation among the soma, nucleus, and the cytoplasm area measured of the myenteric neurons is presented on Table 4.
Figures 3 and 4 present the frequency distribution of the myenteric neurons divided into classes according to the soma area, and Figures 5 and 6 according to the nucleussoma area ratio. 


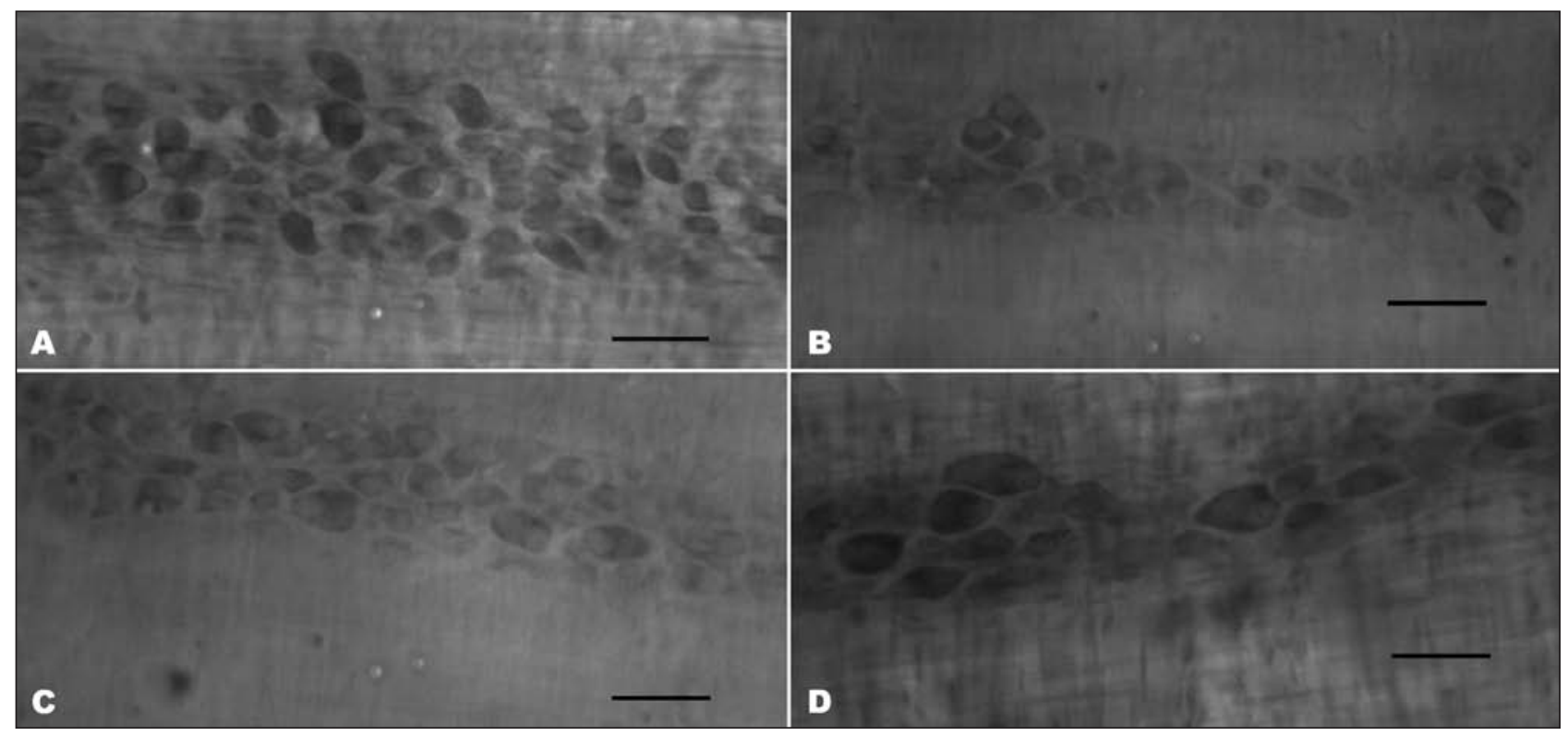

Fig 2. Myenteric ganglions from rat ileum, healthy ( $A$ and $C$ ), or infected with a Genotype III Toxoplasma gondii strain (B and D). Note that there was a discrete atrophy of the neurons of the animals from the control group $(A)$ in relation to the experimental group (B) during the acute phase (24 hr) of the infection, yet neuronal hypertrophy was found for the experimental group $(D)$ in relation to its respective control group (C). Giemsa, bar: $40 \mu \mathrm{m}$.

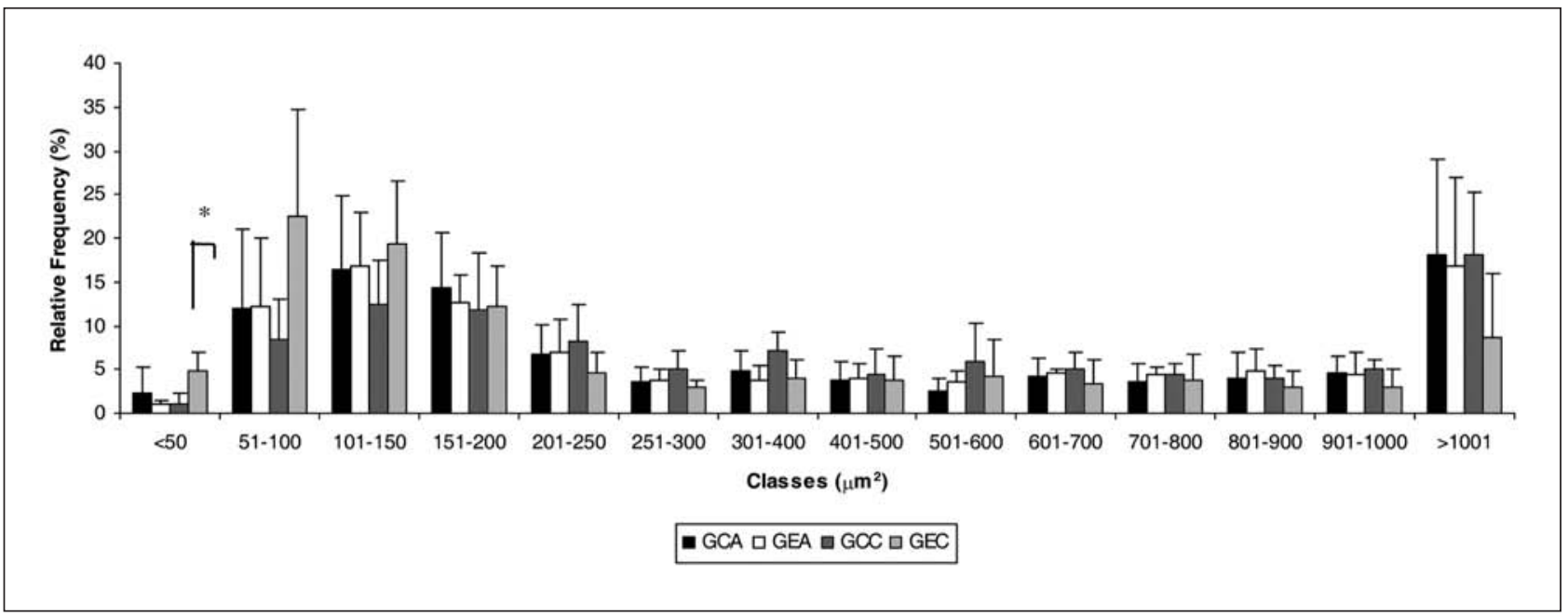

Fig 3. Histogram of the soma area of the myenteric neurons of the terminal ileum from healthy rats (Control Group - CG) and the infected by a Genotype III T. gondii strain (Experimental Group - EG). Columns with asterisks differ significantly ( ${ }^{*} p<0.05$ ).

\section{DISCUSSION}

Toxoplasma gondii is one of the most successful parasite protozoans due to its ability of manipulating the immune system and establishing a chronic infection. There are several $T$. gondii strains. Most of them were identified in Europe and North America being part of three distinct clonal lines: I, II and III' . There is a prevalence of Genotype I, followed by III, in isolated from pigs ${ }^{20}$, dogs ${ }^{9}$, and cats $^{21}$ in Brazil. Genotype III strains isolated in the North Hemisphere have presented low virulence enabling the development of a chronic infection with the formation of tissue cysts in mice ${ }^{8}$; on the other hand, the ones isolated in Brazil are might be lethal for them ${ }^{9}$. Besides, in vitro, bradyzoites develop spontaneously within the neurons, astrocytes, and microglias isolated from rats' central nervous system fetus indicating that these three cellular types may be hosts for the of the parasite encystation ${ }^{22}$. However, there are no reports on the literature whether the neurons and/or glias of the enteric nervous system are also affected by the $T$. gondii. Thus, this study assesses possible alterations of the myenteric rats infected by an isolated Genotype III strain from dogs with neurological symptomatology in Brazil'. 


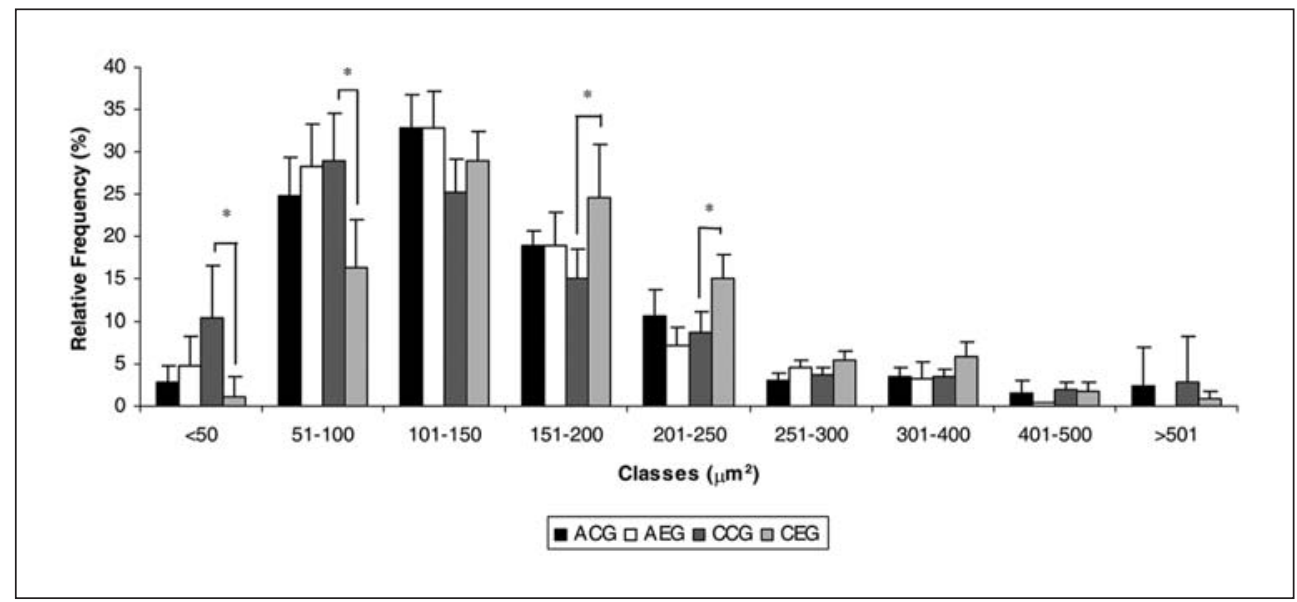

Fig 4. Histogram of the soma area of the myenteric neurons of the descending colon from healthy rats (Control Group - CG) and the infected by a Genotype III T. gondii strain (Experimental Group - EG). Columns with asterisks differ significantly $\left({ }^{*} p<0.05\right)$.

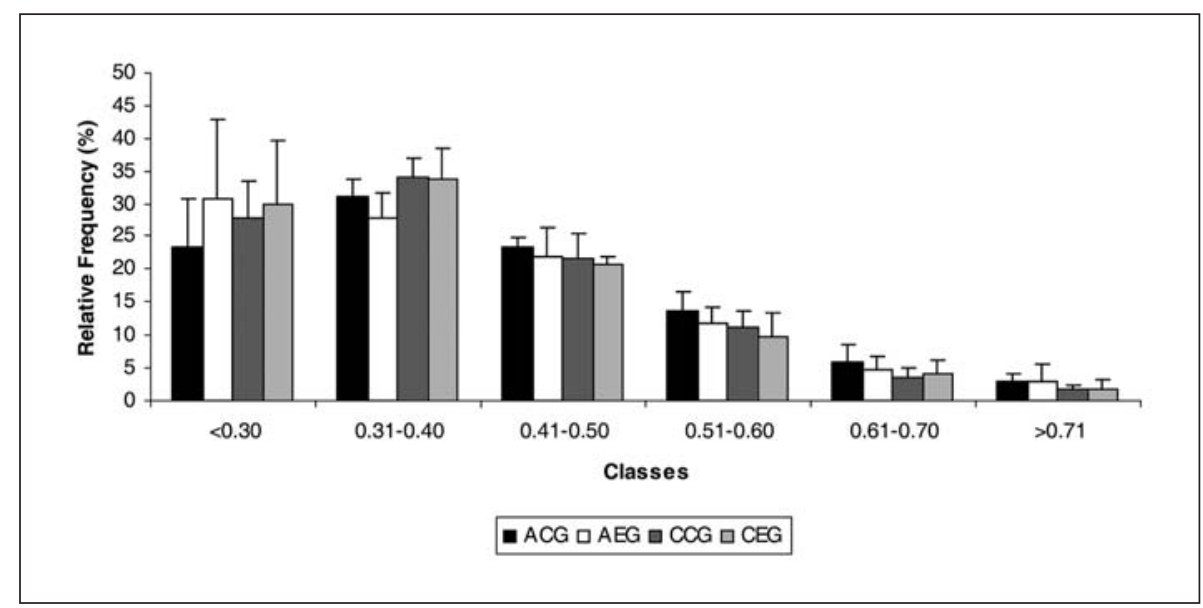

Fig 5. Histogram of the nucleus-perikarion are ratio of the myenteric neurons of the terminal ileum from healthy rats (Control Group) and the infected by a Genotype III T. gondii strain (Experimental Group). Columns with asterisks differ significantly ( $\left.{ }^{*} p<0.05\right)$.

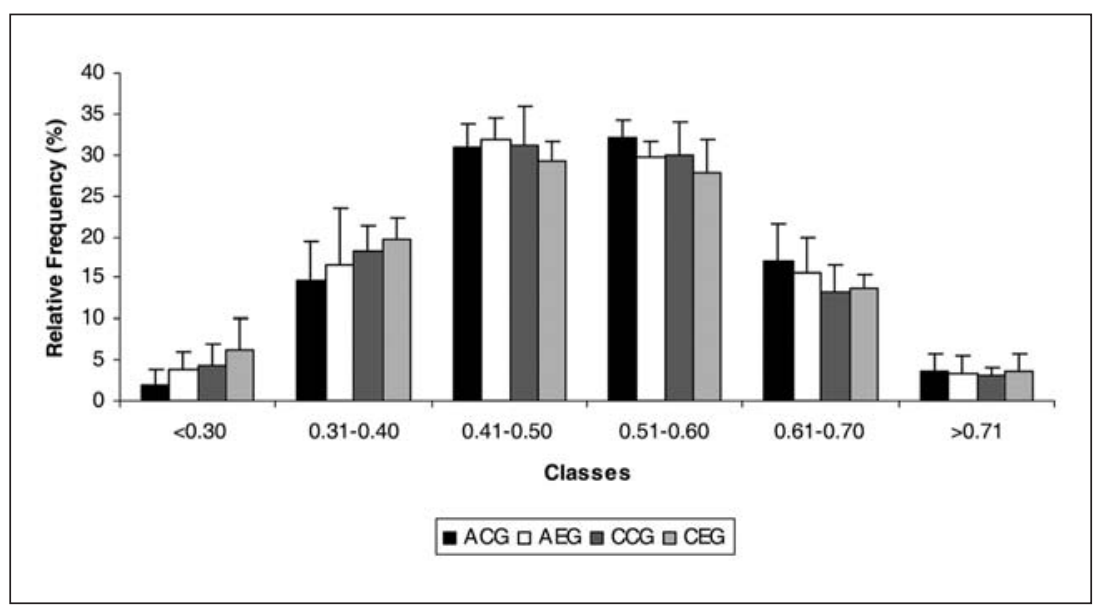

Fig 6. Histogram of nucleus-perikarion area ratio of myenteric neurons of the descending colon from healthy rats (Control Group) and the infected by a Genotype III T. gondii strain (Experimental Group). Columns with asterisks differ significantly ( $\left.{ }^{*} p<0.05\right)$. 
The dimensions of the ileum-jejunum and the total colon, as well as the total number of myenteric neurons of these intestinal segments, observed in this study during the acute phase of the infection ( $24 \mathrm{hr}$ after inoculation), were not altered. On the other hand, it was observed that, in the terminal ileum, the nucleus of the myenteric neurons tended to occupy a smaller portion of the soma $(p<0.05)$, and, in the descending colon, there was a significant reduction of $\sim 7.8 \%$ of the area of the soma, $\sim 9.8 \%$ of the area of the nucleus and $\sim 5.3 \%$ of the area of the cytoplasm $(p<0.05)$. These findings indicate that the infection influenced the metabolism of these neurons, possibly suppressing the genic expression and the synthesis of cytoplasmatic and nuclear protein, resulting in alterations of the cellular volume, maybe as an evidence of cellular lesion.

In the chronic phase (30 days after inoculation), the ileum-jejunum of the experimental animals presented the reduction of the length and width. In this organ, the cells must probably have suffered atrophy and/or hypoplasy. With respect to the neurons of this intestinal segment, a $\sim 52 \%$ reduction of the soma area $(p<0.05)$ was observed, although there were no alterations of the total number of cells. Concerning the descending colon, alterations were not observed in the dimensions of this organ, as well as the total number of the myenteric neurons. However, there was an increase of $\sim 30.8 \%$ of the soma area, $\sim 23.6 \%$ of the area of the nucleus and of $\sim 35.1 \%$ of the area of the cytoplasm $(p<0.05)$. This may indicate that the in terminal ileum, the infection provoked a great reduction of the genic expression of the myenteric neurons whereas the opposite occurred in the descending colon. The genes involved and the interaction mechanism of the parasite with the cellular machinery of the myenteric neurons deserve to be investigated.

Neither neurons from the acute groups nor the chronic was the presence of chromatolysis found, what indicates that there was no axonal lesion. Studies assessing the neurons in the central nervous system also indicate that $T$. gondii does not cause axonal lesion, yet on the pericardium when there is the disruption of the tissue cysts triggering a number of bradyzoites larger than the cell can bear ${ }^{12}$.

The result of the correlation analysis among the measured areas of the myenteric neurons demonstrated that either in the acute phase or in the chronic one, only the degree of correlation among the areas of the soma and the cytoplasm were constant $(p<0.05)$. Therefore, it may be suggested that either the reduction of the soma area of the myenteric neurons of the terminal ileum observed on the CEG group, or the increase of the area of the descending colon neurons of animals of this group, have a more effective participation of the cytoplasm. Thus, the infection by genotype III $T$. gondii probably caused, direct or indi- rectly, molecular alterations which implicated on distinct cytoplasmatic alterations in the terminal ileum and the descending colon. These alterations were possibly a result of the alteration on the genic expression. It may be also considered that this infection might be more aggressive for the neurons of the terminal ileum than the ones of the descending colon, as there was a reduction of the cellular area higher than $50 \%$ for the former, maybe as a result of the parasite invasion in that area was more intensive.

By analyzing the frequency of the neurons divided into classes according to the soma area, it is observed that most of them are within a range of $200 \mu \mathrm{m}^{2}-$ either in the terminal ileum or in the descending colon. It is also remarkable that there was a significant number of neurons bigger than $500 \mu \mathrm{m}^{2}$, what was not observed in the descending colon. These findings were realized in all groups. By assessing the consequences of the infection on the distribution of the neuronal frequency, alterations are noted only in the chronic phase of the experiment: in the terminal ileum, the number of neurons smaller than $50 \mu \mathrm{m}^{2}$ increased whereas there was a reduction on the number of the ones smaller than $100 \mu \mathrm{m}^{2}$ and an increase in the numbers of neurons between 151 and $250 \mu \mathrm{m}^{2}$ in the descending colon.

The distribution of the frequency by considering the nucleus-soma area ratio, that is, the proportion that the nucleus occupies in the soma, most of the neurons in the terminal ileum presented nuclei occupying $30-40 \%$ of the soma; in the descending colon, the area the nuclei occupied $41-60 \%$. There were no significant differences among the experimental groups.

Thus, in general, it was observed that the myenteric neurons of the terminal ileum suffered more morphometric alterations than those of the descending colon, what may be related to the organization of the immune system of these organs. It is extremely common to observe lymphoid nodules (Peyer's patches) in the terminal ileum in relation to the colon. Considering the immune system, studies have noted that the intraperitonial infection with T. gondii recruits inflammatory cells (especially neutrophils) in the inoculation area ${ }^{23}$. Molecularly, it is reported that the NF- $\kappa \beta$ transcription factor has a central role on the regulation of the immune, antiapoptotic and inflammatory response in animals infected with $T$. gondii ${ }^{19}$. It is worth pointing out that the activation of the NF- $\kappa \beta$ translocation by the $T$. gondii is a controversial area, that is, depending on the strain, host cell and species, the $T$. gondii may block the NF- $\kappa \beta$ translocation and inhibit the transcription of the genes involved with the inflammatory response, mainly the 12p40 interleukin (IL) and the tumor necrosis factor (TNF- $\alpha)^{19}$, thus it is possible to observe the differences regarding the virulence of the parasite. 
There are a number of reports on the literature that the increase of the immunological effector cells and their products are responsible for alterations in the neuronal elements ${ }^{5,6}$. In the central nervous system, the microglias attack $T$. gondii with the dependent mechanisms of the interferon (IFN- $\gamma$ ) and the nitric oxide (NO) ${ }^{22}$. The IFN- $\gamma$ is a key cytosine for the resistance against $T$. gondii ${ }^{23,24}$.

Most of the studies related to the immune system/ enteric nervous system interaction involves the irritable bowel syndrome. Through them, it is known that a number of products released from the infiltrated and/or resident leukocytes have demonstrated potential to sensibilize, and even directly activate myenteric neurons and primary afferent intestinal neurons ${ }^{25}$. Within the resident group are the mast cells and muscle macrophages. Mast cells produce bradykinin which eases the enteric secretion of acetylcholine $e^{26}$, besides increasing the excitability of the myenteric neurons ${ }^{27}$ and primary intestinal afferents $\mathrm{s}^{28}$. The muscle macrophages secrete cytokines such as IL-1 $1 \beta$ and IL-6, which act directly on the increase of the excitability of the myenteric neurons ${ }^{29}$ and module the secretion of norepinephrine ${ }^{30}$. Moreover, the intestinal inflammation induces the secretion of cytokines such as IL-1 $\beta$, TNF- $\alpha$, IFN- $\gamma$, and TGF- $\beta$ from the myenteric neurons; however, the identity of the cells which secrete cytokines, neuronal and glias, is not known ${ }^{25}$. It is worth pointing out that the vasoactive intestinal peptide (VIP) plays an important neuroprotector role, either for the central ${ }^{31}$ or enteric ${ }^{32}$ neurons.

This study demonstrated that rats infected either for 24 hours or 30 days did not present myenteric neuron loss; however, during the chronic phase of the infection, in the terminal ileum, these cells became atrophic, and, in the descending colon, hypertrophic. It is suggested that such alterations may be reversible as there was no neuronal loss. By considering the possibility of the T. gondii infect cells from the ENS, as well as these cells being morphologically altered by the cells secreted by the immune system, or even by themselves because of the infection.

\section{REFERENCES}

1. Furness JB. The enteric nervous system. Malden: Blackwell Publishing, 2006:3-28.

2. Bhopale GM. Pathogenesis of toxoplasmosis. Comp Immun Microbiol Infect Dis 2003;26:213-222.

3. Grundy D, Schemann M. Enteric nervous system. Curr Opin Gastroenterol 2006;22:102-110.

4. Rezende JM, Luquetti AO. Megavísceras chagásicas. In: La enfermidad de Chagas y el sistema nevioso. Washinton DC: PAHO Scientific Publication, 1994:160-183.

5. Bogers J, Moreels T, De Man J, Vrolix G, Jacobs W, Pelckmans P, Van Marck E. Schistosoma mansoni infection causing diffuse enteric inflammation and damage of the enteric nervous system I the mouse small intestine. Neurogastroenterol Motil 2000;12:431-440.

6. Balemba OB, Semuguruka WD, Hay-schmidt A, Johansen MV, Dantzer V. Vasoactiintestinal peptide and substance P-like immunoreativities in the enteric nervous system of the pig correlate with the severity of pathological changes induced by Schistosoma japonicum. Int J Parasitol 2001;31:1503-1514.
7. Dubey JP, Beattie CP. Toxoplasmosis of animals and man. Boca raton: CRC Press, 1988.

8. Howe DK, Sibley LD. Toxoplasma gondii coprises three clonal lineages: correlation of parasite genotype with human disease. J Infect Dis 1995;172:1561-1566.

9. Da Silva AV, Pezerico SB, De Lima VY, D'Arc Moretti L, Pinheiro JP, Tanaka EM, Ribeiro MG, Langoni H. Genotyping of Toxoplasma gondii strains isolated from dogs with neurological signs. Vet Parasitol 2005; 127:23-27.

10. Ramsey RG, Gean AD. Central nervous system toxoplasmosis. Neuroimaging Clin N Am 1997;7:1052-1149.

11. Urquhart GM. Parasitologia veterinária. Rio de Janeiro: Guanabara Koogan, 1998:204-207.

12. Hass JA, Shell L, Saunders G. Neurological manifestations of toxoplasmosis: a literature review and case summary. J Am Animal Hosp Assoc 1989;25:256-260.

13. Romero-Piffiguer M, Ferro ME, Riera CM. Potentiation of autoimmune response in rats infected with Toxoplasma gondii. Am J Reprod Immunol Microbiol 1987;14:33-37.

14. Dubey JP, Frenkel JK. Toxoplasmosis of rats: a review, with considerations of their value as an animal model and their possible role in epidemiology. Rev Parasitol 1998;77:1-32.

15. Pachaly JR, Sant'Ana DMG, Araujo EJA, Ciffoni EMG, Acco A. Anestesia of wistar rats (Rattus novergicus) with allometrically scaled doses of ketamine, xylazine, acepromazine and atropine - preliminary report. Arq Cienc Vet Zool 2003;6:195.

16. Silva AV, Cutolo AA, Langoni H. Comparação da reação de imunofluorescência indireta e do método de aglutinação direta na detecção de anticorpos anti-Toxoplasma em soros de ovinos, caprinos, caninos, e felinos. Arq Inst Biol 2002;69:7-11.

17. Barbosa AJA. Técnica histológica para gânglios nervosos intramurais em preparados espessos. Rev Bras Pesq Med Biol 1978;11:95-97.

18. Sant'Ana DMG, Miranda-Neto MH, Molinari SL, Sant'Ana MA. Neuron number in the myenteric plexus of the ascending colon of rats. Arq Neuropsquiatr 1997;55:460-466.

19. Saeij JPJ, Boyle JP, Boothoyd JC. Differences among the tree major strains of Toxoplasma gondii and their specific interactions with the infected host. Trends Parasitol 2005;21:476-480.

20. Santos CBA. Soares RM, Amaru M, Dubey JP, Gennari SM. First isolation and molecular characterization of Toxoplasma gondii from finishing pigs from São Paulo, Brazil. Rev Parasitol 2005;131:207-211.

21. Pena HFJ, Soares RM, Amaru M, Dubey JP, Gennari SM. Toxoplasma gondii infection in cats from São Paulo State, Brazil: seroprevalence, oocysts shedding, isolation in mice, and biologic and molecular characterization. Res Vet Sci 2006;81:58-67.

22. Lüder-Carsten GK, Giraldo-velásquez M, Sendtner M, Gross U. Toxoplasma gondii in primary rat CNS cells: diferential contribution of neurons, astrocytes, and microglial cells for the intracerebral development and stage differentiation. Exp Parasitol 1999;93:23-32.

23. Del Rio L, Bennouna S, Salinas J, Denkers EY. CXCR2 deficiency confers impaired neutrophil recruitment and increased suscepttibility during Toxoplasma gondii infection. J Immunol 2001;167:6503-6509.

24. Suzuki Y, Orellana MA, Schreiber RD, Remington JS. Interferon-gamma: the major mediator of resistance agaist Toxoplasma gondii. Science 1988;240:516-518.

25. Ekblad, E, Bauer AJ. Role of vasoactive intestinal peptide and inflammatory mediators in enteric neuronal plasticity. Neurogastroenterol Motil 2004;16(Suppl):S123-S128.

26. Mulholland MW, Smcone DM. Prostaglandin E2 stimulation of acetylcholine release from guinea pig myenteric plexus neurons. Am J Surg 1993;166:552-556.

27. Kimball BC, Mulholland MW. Neuroligands evoke calcium signaling in cultured myenteric neurons. Surgery 1995; 118:162-169.

28. Ozaki N, Gebhart GF. Characterization of mechanosensitive splanchnic nerve afferent fibers innervating the rat stomach. Am J Physiol Gastrointest Liver Physiol 2001;281:G1449-G1459.

29. Kelles A, Janssens J, Tack J. Eletrical behaviour of interleukin-1 beta (IL-1 beta) and prostaglandin-E2 (PGE2) on colonic myenteric neurons. Neurogastroenterol Motil 2002;14:321-330.

30. Collins SM, Hurst SM, Main C, et al. Effect of inflammation of enteric nerves: cytokine-induced changes in neurotransmitter content and release. Ann NY Acad Sci 1992;664:415-424.

31. Gressens P, Hill JM, Gozes I, Fridkin M, Brenneman DE. Growth factor function of vasoactive intestinal peptide I whole cultured mouse embryos. Nature 1993;362:155-158.

32. Sandgren K, Lin Z, Svenningsen AF, Ekblad E. Vasoactive intestinal peptide and nitric oxide promote survival of adult rat myenteric neurons in culture. J Neurosci Res 2003;72:595-602. 